\title{
AFFORESTATION AS A FACTOR OF PHYSICALLY GEOGRAPHICAL CHANGING: A CASE STUDY OF DELIBLATO SAND
}

\author{
Marko Sedlak*1 \\ * University of Belgrade - Faculty of Geography, Belgrade
}

\begin{abstract}
The paper analyzed basic physical-geographical characteristics and changes caused by afforestation. The aim of the paper is to point out the transformation of the natural environment initiated by afforestation, to present positive and negative implications of this action, and to emphasize the importance of the consideration of the cause-and-effect relationships during concrete action in the field. By applying analytical - synthesis and comparative methods, a presentation of the natural features of the Deliblato sand and changes that were made as a result of afforestation, is given. The results of the research present positive changes which are reflected in the stabilization of unbound sand, development of the pedogenetic process and improvement in the microclimate conditions in the forested sectors. Negative changes in afforestation are reflected in the reduction of the area's steppe vegetation and the consequent intensity of forest fires.
\end{abstract}

Keywords: Deliblato sand, afforestation, eolic erosion, microclimate, pedogenetic process, forest fires.

\section{Introduction}

Afforestation includes planned and dedicated activities which are based on increasing surfaces under forest vegetation with the aim of improving existing conditions in a given territory. The importance of the conservation of existing

1 Corresponding author: M. Sedlak, student, University of Belgrade - Faculty of Geography, Studentski trg 3/III, Belgrade; e-mail: maresedlak1@gmail.com 
forest complexes and revitalization of degraded communities' forest vegetation is the focus of interest scientific circles who are dealing with the problem of sustainable development and establishing an ecological balance. The purposes of afforestation have different territorial ranges: global (improving air quality, mitigation of climatic extremes), regional (at the level of one or more countries) and local (within one or more municipal units with the aim of improving existing conditions in a smaller radius).

Changes in the territory of the Deliblato sand related to afforestation processes in the past two centuries, are the result of anthropogenic impacts. Conscious and unconscious activities which led to a change in vegetation cover, and a transformation in physicalgeographical characteristics of these territories. They reflect the changes in geomorphological characteristics and recent erosive processes, characteristics of the pedological blanket, and impact on steppe vegetation and the intensity and dynamics of forest fires (Milenković, 2010).

Various changes generated as a result of afforestation point to positive and negattive afforestation effects. In the concrete case study of Deliblato sands, positive influences of afforestation are presented related to the prevention of eolic erosion, improvement of microclimate conditions and development of the pedogenetic process as a result soil enrichment with humic substances. Negative implications are caused by an unplanned basis of afforestation. The increase in the participation of conifer species in the structure of the forests reflected the encouragement of high forest fires that devastated enormous areas. The development of the forest community has led to the spread of invasive plant species and disturbances of the habitat of steppe vegetation. The intensification of afforestation would lead to bringing the native steppe vegetation to the brink of extinction. This set of changes points to the importance of preserving the forest complex in this area but also caution and flexibility in the examination of the changes that result from the transformation of this territory.

\section{Research area and methodology of research}

The area of research on the impact of afforestation on the transformation of the natural environment is limited to the territory of the Deliblato Sands. It is located in the southern part of Banat or in the southeastern part of Vojvodina. It stretches in the direction of the southeast - northwest at a length of 35 kilometers and a width of 15 kilometers. It covers an area of about $350 \mathrm{~km}^{2}$. It is limited to the following settlements: Grebenac, Nikolinci, Banatski Karlovci and Alibunar from the north and northwest, Mramor and Deliblat from the southwest and Banat Topol and Dubovac from the southeast. The Deliblato sands is an eolian formation morphologically located at the bottom of the Pannonian Basin. It is surrounded by the Banat woody plateau. The basic physical-geographical de- 
terminants of this area are the conditions of the steppe-continental climate, the small representation of hydrographic objects and the dependence on the depth of the issued, autochthonous xerophytic steppe vegetation and sandy soils (Stankević i Pavićević, 1963; Живановић и Гајић, 2017; Gajić, 1983; Ducić et al., 2008; Milenković et al., 2013; Kadović et al., 2014).

In this paper analytical - synthetic, statistical and comparative methods were used. The impact of afforestation on changes in physical geography was considered using a number of literary sources: textbooks, scientific papers and spatial plans. Based on them, data was collated related to the situation and changes in the Deliblatoan sands in the past and the factors that were conditioned on them. Analytical interpretation of the results obtained by their research formed a synthesis related to the modification of the original conditions in nature under the influence of afforestation. From the statistical methods used, data was collated on changes in the forest complex area and participation of the most important plant species. Also, with the help of statistical evidence of the number of forest fires, the burnt surface, the structure of the fired area (forests and other areas), the division of the observed period into time sections was made, on the basis of which the arithmetic mean of numerical values is calculated. A comparative analysis has established a causal relationship between the changes caused by the increase in the share of conifers in the structure of forest complexes and the increase in the desalted areas of predominantly forest communities. The combination of the statistical and comparative method indicates the relationship between the afforestation of the Deliblatska sands with black and white pine and the incitement of forest fires.

\section{The history of afforestation of Deliblato sands}

The changes of forest vegetation until the $18^{\text {th }}$ century were the result of historical circumstances in that area. The successive settling and emigration of the population accompanied by frequent battles, led to the reduction and increase of the forest communities. The degradation of forests in the territory of Serbia includes the period of medieval Serbia and the period of migration movements and settling in the early $19^{\text {th }}$ century (Raktnić i Dražić, 2007). Based on records from the Middle Ages, it appears that the Deliblato sands at that time was forested. Remnants of bones and horns of deer represent evidence that in the past the area the Deliblato sands was under forest vegetation (Stankević i Pavićević, 1963). At the end of the $17^{\text {th }}$ century (1691), there was a battle in this area, whose historical records mention forest complexes. This affected the reduction of the area under the forest cover on the territory of the Deliblatska sands, in contrast to the renewal of forest vegetation in demographically emptied Serbia (Ratknić i Dražić, 2007). After that, large areas of unbaked sand appeared in this area. 
The beginning of the $18^{\text {th }}$ century marked the expulsion of the Turks across the Danube. On the geographical map that originates from this period (17231725), the Deliblatska sands are shown as a plain without surfaces under living sand (Milenković, 2010). In the period of Austro-Hungarian rule, some sources of bonding for afforestation of the Deliblato sands cost about a billion golden crowns (Jakubov, 1964).

The year 1818 is considered as the starting year for afforestation of the territory of the Deliblatska sands. At that time the area of the Deliblatska sands was managed by the Banat Border Management Directorate based in Bela Crkva. Afforestation was accompanied by the introduction of controlling measures related to the prohibition of woodcutting and grazing of cattle. Afforestation was mainly done in the peripheral parts of the Deliblato sands, while in the central parts there was little work done on this issue. The most important species in the afforest area of the Deliblatska sands were birch, white and black poplar, white and black pine and lombardy poplar. At that time, there were also afforestation attempts with other deciduous species: brest, oak and lime. The birch trees fell quickly, the pines showed some better success, and the poplars were best shown. Peat poplar was followed by sowing grass and covering sand with straw, corn and reed (Gajić, 1983; Milenković, 2010).

The second reforestation period covers the period from 1843 to 1871. In 1843, the Business Administration for Sandblasting was established after the Banat Forest Border Directorate was abolished. This period was not significant in terms of afforestation of this area. Raised cultures from the previous period were destroyed. Excessive tree felling and grazing of livestock led to the reduction of forest surfaces, so the work of the previous period did not have any function. Minor afforestation was the result of ineffective means of managing afforestation, as it was considered that afforestation from the previous period was sufficient and that the forest vegetation would spontaneously expand to the inner parts of the sandstone. The only significant shift was made in the field of introducing species of haymakers to the Deliblatska sands habitats (Gajić, 1983; Milenković, 2010).

The third period covers the period between 1872 and 1877. During this period the Deliblato sands was under the administration of the Ministry of Finance, after the Military Border was abolished in 1872. During this period, a small area was forested, but the significant change was the increasing use of chamomile (Gajić, 1983; Milenković, 2010; Stankević i Pavićević, 1963).

During the next period, from 1878 to 1897, the Hungarian Royal Directorate of Forests (headquarters in Lugos) managed activities at the Deliblatska sands. This period is called the "forest period". In the afforestation, the most commonly used seedlings were chamomile, poplar and pine trees. In addition to these species, there were attempts to grow oak, sour wood, puddles and wal- 
nut. Increasing the area under the forest contributed to the application of new technology for afforestation and sandblasting. It was based on the cutting of the branch of the tower and the laying on the sand in rows, between which the afforestation was done with acacia in a $2^{\text {nd }}$ row (Gajić, 1983; Milenković, 2010).

The fifth reforestation period covered the twenty-year period between 1898 and 1918. During this period, the Deliblatska sands were under the administration of the Ministry of Agriculture. Afforestation was mainly done with the help of cormorant cultures, American ash, sesame, walnut, oak and black pine oak. The year 1907 is considered the final year of sand binding. During this period (1912), the first Editors' study came into force, whose application led to the division of forests into 8 sections, and even to departmental units, which were separated by the cut (Milenković, 2010; Gajić, 1983; Stankević i Pavićević, 1963).

Table 1. Period of afforestation of the Deliblato sands until 1918

\begin{tabular}{|c|r|r|r|r|r|}
\hline The period of afforestation & 1818-1842. & 1843-1871. & 1872-1877. & $\mathbf{1 8 7 8 - 1 8 9 7 .}$ & $\mathbf{1 8 9 8 - 1 9 1 8 . ~}$ \\
\hline Grounded areas (hectar) & 5131,60 & 4648 & 470 & 3505 & 6765 \\
\hline
\end{tabular}

Source: Milenković, 2010.

The period after 1918 marks another important chapter related to the modification of the territory of the Deliblato sands by afforestation. It is also broken down into several stages. The differentiation being made is based on differences in the method of afforestation and the selection of plant crops in their participation.

In the first period (1919-1933), 1390 ha were forested. Acacia species were predominantly used, somewhat less, pine trees, and there were attempts with the introduction of poplar. Good afforestation results were evident after the soil was processed. More afforestation was done on parts of the territory where the initial attempts were not successful (Gajić, 1983).

In the following period of reforestation, which lasted between 1933 and 1950, the afforestation of acacia and poplar, and to a lesser extend, pines was dominant. The species that were used in afforestation were lime, oak and birch. There was a change in the way rejuvenation of acacia species. Shrinkage began to fall, so that the acacia was restored from the vein, instead of rejuvenating the acacia species from the stump, as was then applied (Gajić, 1983).

The following period, which lasted from 1955 to 1966, marked changes in the means of afforestation and the goals of restructuring forests. There was a decrease in the share of the acacia in afforestation, and the planting of pine species was intensified. Work on the revitalization of degraded forests of acacia and poplar was performed by replacing species or reorganizing trees into high stems (Gajić, 1983).

The next period, which lasted from 1967 to 1978, emphasized the improvement of the quality of the forest fund and forest care. In this period, a small area of 415 ha was planted (Gajić, 1983). 
Afforestation within the fifth period (1979-1997) was done with emphasis on afforestation of the Deliblato sands in deciduous species, because conifer species fueled forest fires (Gajić, 1983).

Table 2. Period of afforestation of the Deliblato sands after 1918

\begin{tabular}{|c|r|r|r|r|r|}
\hline The period of afforestation & 1919-1933. & 1933-1950. & 1951-1966. & 1967-1978. & 1979-1997. \\
\hline Grounded areas (hectar) & 1390 & 1021 & 5025 & 415 & 895 \\
\hline
\end{tabular}

Source: Milenković, 2010.

Based on the enclosed data, there were changes in the area of forest complexes and plant species used for afforestation. The three dominant species used for afforestation were acacia, poplar and pine trees.

The area under forests in the territory of the Deliblatska sands varied until the middle of the 20th century. First, there was a decline in the area of forest communities, so that in the period between 1933 and 1953, the growth of forest communities was observed as 321 ha. The second half of the 20th century marked the increase in forest areas. This increase was due to the intensification of raising coniferous forests, which was marked between 1953 and 1987. After that, the fall of the area under the forests resulted from the intense forest fires that affected this area.

During the period from 1912 to the mid-20th century, the largest percentile share of forest complexes consisted of seedlings of acacia (over 85\%). After that, their percentage share gradually decreased. This change occurred as a result of the use of conifer species (pines) during afforestation. The increase in the percentage share of pines in the structure of forest complexes correlated with the increase in area under forests (period between 1953 and 1987). After that, there was a decline in its share. This change occurred as a result of a change in the way of afforestation and suffering from forest fires that are most susceptible to the blight.

Table 3. Participation of plant species in the reforestation structure

\begin{tabular}{|r|r|r|r|r|r|r|r|}
\hline Year & Forest area & \multicolumn{1}{c|}{ Acacia } & \multicolumn{1}{c|}{ Poplar } & \multicolumn{1}{c|}{ Pines } & Acacia (\%) & Poplar (\%) & Pines (\%) \\
\hline 1912. & 12180 & 7040 & 4860 & 280 & 57,8 & 39,9 & 2,3 \\
\hline 1933. & 9552 & 7685 & 1184 & 683 & 80,4 & 12,4 & 7,2 \\
\hline 1953. & 9873 & 8473 & 874 & 526 & 85,8 & 8,9 & 5,3 \\
\hline 1967. & 13740 & 9042 & 905 & 3793 & 65,8 & 6,6 & 27,6 \\
\hline 1977. & 13933 & 9014 & 636 & 4283 & 64,7 & 4,6 & 31,7 \\
\hline 1987. & 18032 & 11301 & 816 & 5916 & 62,7 & 4,5 & 32,8 \\
\hline 1997. & 14828 & 10946 & 880 & 4312 & 73,8 & 5,9 & 21,3 \\
\hline
\end{tabular}

Source: GJ „Banat“,2017. 
Today, the most widespread species of forest trees on the territory of the Deliblatska sands are: chopper (Robinia pseudoacacia), black pine (Pinus nigra) and white pine (Pinus sylvestris). These types of trees are predominantly the result of the activity of the men who used these trees for afforestation of the Deliblatska sands at different times (Milenković, 2010).

\section{Results of research and discussion}

The influence of forest vegetation on the stabilization of erosive processes

The geomorphological characteristics of the territory of the Deliblato sands favor the process of eolic erosion. The process of eolic erosion is present in arid and semiarid areas. The greatest influence on the erodible fraction on the territory of the Deliblatska sands has the share of sand, dust and humus. The most important factors that influence the soil resistance to eolic erosion are the size and stability of structural aggregates. The land of the Deliblato sands is classified into 3 texture classes: sand, sandy loam and loamy sand (Живановић и Гајић, 2017). On the basis of these parameters, the land of the Deliblato sands belongs to different categories of erosibility. The textural sand class belongs to highly erodable soils, loamy sand with medium erodable soil, while sandy clay belongs to poorly erodable soil (Кадовић и сар., 2014). In addition to the aforementioned factors, eolic erosion process in the territory of the Deliblatska sands is a result of characteristic pedological features (moisture content, chemistry, content of organic components), climatic characteristics, vegetation cover and the influence of anthropogenic factor (Kadović et al., 2016).

Changes in the vegetation cover play an important role in encouraging and calming the erosion process. The territory of the Deliblatsko sands is a good example of the influence of historical circumstances on the changes of forest cover, whose destruction would encourage the eolic erosion process. Subsequent to afforestation, the eolic erosion process is stabilized.

The flora of the Deliblato sands has a decisive influence on the genesis and stability of the easily destructive soil of the Deliblatska sands below which there are huge masses of unbound sand. The 19th and the beginning of the 20th century was marked by the movement of huge sand masses from the Deliblatska sands to the most fertile soil of the Pannonian Basin. Acacia played a major role in the stabilization of moving sand because of its deep root, growth rate and tolerance for exhaling and setting sand (Gajić, 1983). Based on the recent state, eolic processes in the territory of Deliblato sands are dead. The importance of preserving the existing vegetation is great because at a small depth below the 
surface horizontal of the land there is a powerful layer of unbaked sand, which would be restarted after the eventual destruction of forest vegetation.

\section{The influence of forest vegetation on microclimatic changes}

The area of the Deliblato sands has a dry type of subhumid climate. The coldest month is January, and the hottest, June. In 1903, a meteorological station was set up in Flamunda, which was operational until 1960. The average annual temperature in the territory of the Deliblato sands is $11^{\circ} \mathrm{C}$. The average amount of precipitation in the territory of the Deliblatska sands is over $660 \mathrm{~mm}$ in Šušara, or over $670 \mathrm{~mm}$ at the Flamunda meteorological station. The most important winds in the territory of the Deliblatska peščara come from the south-east direction (basket) and from the northwest. The dry, cold and watery winds of the basket have a great impact on the climatic conditions of this area (Milenković, 2010; Gajić, 1983).

The absence of meteorological stations makes it difficult to monitor contemporary climate change in this area. On the territory of the Deliblatska sands, climate change is noticeable in terms of changing the temperature regime and the amount of precipitation per year. Between 1948 and 2002, an increase in air temperature was observed of an average $0.061^{\circ} \mathrm{C}$ per decade and a decrease in the amount of atmospheric precipitation of $1.48 \mathrm{~mm}$ per decade (Ducić et al., 2008). According to the latest observations in the last decade, an increase in air temperature of $0.52^{\circ} \mathrm{C}$ was observed, as well as an increase in precipitation for the same period of $35 \mathrm{~mm}$ (Kadović et al., 2014).

The particular specificity of the Deliblato sands in terms of climate is microclimate characteristics. The biggest impact on them is the type of substrate. The microclimate of the Deliblato sands is distinguished by early and late frosts, starting from September and occurring during May and June (Gajić, 1983; Stankević i Pavićević, 1963).

Vegetation has a great influence on microclimatic characteristics. Barefooted surfaces condition large temperature amplitudes. Forest surfaces have a great influence on the reduction of these temperature extremes. Temperature changes are evident in the air and in the soil. The forest lands of the Deliblato sands are distinguished by significantly lower temperature amplitudes during the year. In addition, the humidity of forest land is incomparably higher in comparison with the land of sandstone and steppe habitats (Gajić, 1983; Stankević i Pavićević, 1963).

Trees mitigate temperature extremes, so that the decrease temperatures by several degrees, and in winter they increase. By evapotranspiration trees lead to increased air humidity. Increasing the area under the forests has a major impact on the deceleration of winds that are exposed to the territory of the Deliblato sand from the south-east direction (Raktnić i Dražić, 2007). 
Based on a comparative analysis between the results obtained by monitoring the changes in climatic elements (air temperature and precipitation) and the area of forested area, it is concluded that the afforestation process did not have an impact on climate changes at the entire sandy level. Changes are visible only on areas that are more intensively forested. Afforestation of the Deliblato sands caused only microclimatic changes, but did not significantly affect changes on the entire sandy level.

\section{The influence of forest vegetation on the development of the pedogenetic process}

Vegetation and soil are in direct relation. Vegetation determines the occurrence, characteristics and development of the pedogenetic process, while the soil affects the development of plant species. In the territory of the Deliblato sands, the vegetation type of the forest has the greatest influence on the evolution of the soil in relation to other types of vegetation (grassland and steppe communities). The influence of forest on the formation of productive soil is manifested in a large amount of organic matter produced by them and which are further expanded by biochemical processes (Košanin i Tomić, 2002).

In the territory of the Deliblato sands, the dominant pedological representative is arenosol (Eolian sand). This type of land was created under the influence of wind. The formation of this type of soil is associated with the process of sand stabilization and gradual development of the soil. They are developed on a lithological basis from sand of a different mineral composition: quartz, ferrite and carbonate. Based on the humus content, the arenosoles of Deliblato sands belong to the category of subarid-subhumidic, characteristic of steppe areas. Its genesis is favorable by climate conditions with a small amount of precipitation that makes the development of vegetation difficult. Eolic lands can be on the move or calm. The development of vegetation cover affects the stabilization of this land (Đorđević i Radmanović, 2018; Lješević, 2003).

The evolution of soil on the eagle sand of the Deliblato sands under the influence of forest vegetation follows the deepening of the solum, the formation of structural aggregates, the increase of humus content and the flushing of carbonates. The forest vegetation type causes the accumulation of organic matter in the surface layers of the soil. Organic substances that reach the surface of the soil in the forest can hardly be explained over a year. In this way, a layer of forest rug is formed on the surface of the soil under the forest. It leads to accumulation of nutrients, changes in chemical and physical properties of the soil and affects its water, heat and air regime. This leads to high humus content in the surface profile, which decreases with depth increase. The filling of carbonates from the profile under the influence of humus substances is an indicator of the high degree of evolution of the pedogenesis process (Đorđević i Radmanović, 2018; Košanin i Tomić, 2002). 
On the most irregular type of soil, there are gray grassland forests. On the chernozem, which is based on the carbonate eolian sand, there are forests of oak and white linden and forests of spherical medunce and cereals (Košanin i Tomić, 2002).

Gray grassland forests affect the formation of pedologic horizons on the sirozem. Sirozem belongs to the category of undeveloped soils with the profile of Olf - Oh - (A) - C, with the beginning of the formation of horizon A. Horizon of sirozem has a capacity of about $40 \mathrm{~cm}$, brown is a color with low content of clay and a weak attachment. The reaction is poorly alkaline or neutral. The intense accumulation of humus is the result of the forest community. Forest vegetation of this type affects the forming of Olf Horizon, which consists of one- year-old leaves. Good humification conditioned the formation of the horizon Oh, which is distinguished by the compactness and protuberance of the fine wire, up to $5 \mathrm{~cm}$ thick. By forming Oh horizons, the land is enriched with nitrogen. In some parts, the combination of mineral and organic components is partly noticeable (Košanin i Tomić, 2002).

White oak forests with oaks include a floor of trees of about 20 meters high, with a busy floor of a bushes. They are present on slopes up to 20 degrees and predominantly on chernozems, occurring in the border zones between the sandstone and the woody plateau. This forest community occurs predominantly on black sand. This land belongs to the category of developed and belongs to humus - accumulative soil. The plot has profiles A - AC - C. According to the texture, the soil is a sand-clay composition. According to the reaction, it is weakly neutral or alkaline. It is distinguished by its color as a result of the richness of organic matter. The organogenic horizon of this year's leaf is formed on the surface. The high content of clay (15-20\%) indicates the high degree of pedological evolution of this land. The slow process of humification causes a higher level of xerothermity of the habitat and an increased quantity of oak leaves. The increased content of plant residues is in direct relation to the share of humus and carbonate. Herbal residues lead to an increase in humus content which leads to the washing of carbonates from surface to deeper soil layers. A higher degree of soil evolution is present on the land under the coarse-grained blanchard and the cereal in relation to the lands under the linden forests. The evolution indicator is the washing of carbonates to greater depths on the lands covered by the brass and cereal forests, compared to the lands under the linden forests. The share of organic matter of oak trees causes a discrepancy between humification and mineralization in the surface parts of the soil (Košanin i Tomić, 2002). 


\section{The impact of afforestation on other plant communities}

In the territory of the Deliblatska sands, 4 vegetation types are distinguished: sandy, steppe, wetland and forest vegetation. Formation of the Deliblato sands flora was mainly in the postglacial era, so that it is in a geological view of the recent origin. Forest type of vegetation includes smaller areas of autochthonous forests. The occurrence of forest vegetation on the sand has the character of a forest - steppe. In the conditions of the steppe climate, the occurrence of forests is related to moisture sides and areas that are less exposed to insolation (north, northeast and northwestern exposure). Deciduous forests in the territory of the Deliblato sands are indigenous, while the conifers are predominantly the result of anthropogenic activity (Gajić, 1983; Дуцић и Миловановић, 2004; Миленковић, 2010).

The development of forest vegetation negatively affects populations of steppe plants. The reduced reproductive capacity of steppe plants is influenced by biochemical phenolic compounds of dominant woody species, competition for water and mineral matter from the soil necessary for their growth and development. Through litter consisting of partially decomposed leaves and twigs, there are favorable conditions for the development of phenolic acids. At the site of Flamunda, where the population of the Banat peak population is located, a decrease in these individuals was observed as a result of the influence of the forest complex of oak (Anačkov et al., 2013; Đurđević et al., 2000; Popović et al., 2014).

The process of mass afforestation has spurred the process of spreading invasive species (acacia), which led to the reduction of the distribution area of plant species. Raising surfaces for growing plantations of fast-growing species has also prompted the expansion of invasive species (Milenković et al., 2013; Milenković i sar., 2018).

Forest vegetation leaves consequences for individual steppe species, but also for the appearance of steppe habitats. The result of the mismatch between the raising of forest complexes and the preservation of the native steppe flora is the emergence of uniformity and fragmentation of steppe habitats. The uniformity process denotes the decline in biodiversity, which destroys the structure of the natural cover, so these areas become less similar. Fragmentation of the habitat refers to the partial representation of steppe species on the surface of the Deliblato sands, which is a consequence of the spread of the forest vegetation type (JP „Zavod za urbanizam Vojvodine“, 2013; Puzović i sar., 2015). 


\section{The impact of afforestation on the incitement of forest fires}

Forest fires represent the uncontrolled movement of fire on the forest surface. The conditions considered to be the initiators of the fire are: fuel, oxygen and heat. The division of fire was carried out in 4 types: subterranean, terrestrial, medium and high. The criterion on the basis of which the above classification is performed, is the part that burns in the stand (Драгићевић и Филиповић, 2009; Миленковић, 2011; Шорак и Рвовић, 2016).

Differences in exposure to fire occur depending on the structure of the trees and their dominant representation. It is known that the conifers are significantly more exposed to the fire due to the content of essential oils and resins that these plants have in its composition. The mills are significantly more threatened than high fires, while the leaves are mostly endangered by low fires. Trees with thick corks are more exposed to the effects of high fires, while the trees with a thinning of the coral predominantly suffer from the consequences of terrestrial fires. In addition to the direct effect of fire on plants, there are other consequences. The cultures that have suffered damage as a result of exposure to fires represent a favorable environment for the spread of harmful insects and pathogenic fungi (Gajić, 1983; Миленковић, 2010; Шорак и Рвовић, 2016).

Afforestation of the Deliblato sands with the monocultures of conifers in the second half of the 20th century has caused the most intense fires. Their destructive effect manifests itself in the form of a flammable surfaces that has been affected by their action. Changes in terms of the number of fires, deforestation and the share of forest areas in them are shown on the basis of ten-year time sections. A large share of forest vegetation (over 50\%) in the structure of the burned area is an indicator of the impact of afforestation on congestion by firefighters. The time sections in which the share of forest vegetation in the structure of the scorched surface has increased corresponds to the period in which there is an increase in the share of pines in the afforestation structure.

The link between the period of afforestation and the number of fires is difficult to establish. Based on the observation of the total number of fires in given time intervals, an oscillation of their number is observed. In the period 19681977. during the year, there is an increase in the number of fires compared to the previous ten-year period. After that, the number of fires decreases. 
Table 4. Data on forest fires in the territory of the Deliblato sands

\begin{tabular}{|c|r|r|r|r|r|r|}
\hline Period & $\begin{array}{c}\text { Number } \\
\text { of fires }\end{array}$ & $\begin{array}{c}\text { Fogged } \\
\text { surface (ha) }\end{array}$ & Forests & \multicolumn{1}{c|}{$\begin{array}{c}\text { Other } \\
\text { surfaces }\end{array}$} & Forests (\%) & $\begin{array}{c}\text { Other surfaces } \\
\text { (\%) }\end{array}$ \\
\hline $1958-1967$. & 60 & 892.01 & 356.21 & 535.8 & 39.9 & 60.1 \\
\hline $1968-1977$. & 65 & 2721.26 & 1504.74 & 1216.52 & 55.3 & 44.7 \\
\hline $1978-1987$. & 41 & 244.56 & 96.65 & 147.91 & 39.5 & 60.5 \\
\hline $1988-1997$. & 23 & 5013.45 & 3143.1 & 1870.35 & 62.7 & 37.3 \\
\hline
\end{tabular}

Source: Milenković, 2010.

In the period between 1953 and 1967, the percentage of pine seedlings in the structure of forest vegetation increased fivefold (from 5.3\% to 27.6\%). In the period between 1967 and 1977, the percentage of pine trees increased from $27.6 \%$ to $31.7 \%$, and the share of forests in the total surface area of the deforested area was 55.3\%. In the period between 1977 and 1987, a further increase in the share of pines in the structure of forest areas was identified (from $31.7 \%$ to $32.8 \%$ ), while the share of forests in the structure of fires was $39.5 \%$. The period between 1988 and 1997 marked the period of the most intense high fires with a 62.7\% share in the structure of the fired area. Of the 4 largest fires in the history of the Deliblatska sands, two fires took place in this intermediate period (1990 and 1996). In the same period, there is a decrease in the share of pine trees in the structure of forest areas as a result of the fire falling from trees.

\section{Conclusion}

Afforestation has a major impact on the modification of the original natural terrain. Experts from various profiles point to the positive effects of forest complexes at global, regional and local level. The analysis of the afforestation impact on the territory of the Deliblatska sands indicates the changes that occur in nature as a consequence of this. In addition, both positive and negative changes occurring after afforestation have been reported. The highlighting of positive changes confirmed the previously considered results of this activity. On the other hand, the analysis of negative changes, which is much less talked about in literature, aims to point out the necessity of planned use of space. Afforestation of the Deliblatska sands, the initially active sand is stabilized and the land is enriched with humus substances. It also led to the narrowing of the area of native steppe vegetation, the spread of invasive plant species and the incitement of forest fires, which put into question the positive effects of the forests of this area. 


\section{References}

Anačkov, G., Rat, M., Radak, B., Igić, R., Vukov, D., Rućando, M., ... \& Boža, P. (2013). Alien invasive neophytes of the Southeastern part of the Pannonian Plain. Central European Journal of Biology, 1. doi: 10.2478/s11535-013-0225-6.

Gajić, M. (Ed.). (1983). Flora Deliblatske peščare. Prirodno-matematički fakultet OOUR Institut za biologiju.

Ducić V., Milenković M., Radovanović M. (2008): Contemporary climate variability and forest fires in Deliblatska peščara. Journal of Geographical Institute Jovan Cvijić SASA, 58, pp. 59-73.

Ducić, V., Milovanović, B. (2004). Termičke specifičnosti Deliblatske (Banatske) peščare. Zbornik radova Geografskog fakulteta, Sveska LII.

Djurdjevic, L., Dinic, A., Stojcic, V., Mitrovic, M., Pavlovic, P., \& Oldja, M. (2000). Allelopathy of Paeonia officinalis L. 1753 ssp. banatica (Rochel) Soo 1945, a Pannonian endemic and relict species. Arch Biol Sci (Belgrade), 52, 195-201.

Đorđević, R.A., Radmanović, B.S. (2018). Pedologija. Beograd: Univerzitet u Beogradu - Poljoprivredni fakultet.

Kadović, R., Bohajar, Y.A.M., Perović, V., Belanović-Simić, S., Todosijević, M., Tošić, S., Anđelić, M., Mlađan, D., Dovezenski, U. (2016). Land Sensitivity Analysis of Degradation using MEDALUS model: Case Study of Deliblato Sands, Serbia, Archives of Environmental Protection vol. 42 no. 4 pp. 114-124.

Кадовић, Р., Миљковић, П., Перовић, В., Живановић, Н., Mansouri Ali Bohajar, Ү., Белановић Симић, С. (2014): Анализа еродибилне фракције песковитих земљишта Делиблатског песка, Часопис за уређење бујица и заштиту од ерозије „Ерозија“ 40, 38-52, Београд.

Kadović, R., Spasov, P., Ali Bohajar Y.M., Belanović, S.S., Košanin, O. (2014). Analysis of aridity indicators in the Deliblato sands. Bulletin of the Faculty of Forestry 109: 97-112.

Lješević, M. (2003). Geografija zemljišta. Nikšić: Univerzitet Crne Gore, Filozofski fakultet i Geografsko društvo Crne Gore.

Milenković, M., Radovanović M., Ducić, V. \& Milošević, M. (2013). Fire protection problems with large forest fires in Deliblatska peščara (Serbia), Book of Abstract of International conference: Natural hazards - links between science and practice, Belgrade, Serbia, October 8-11th, 2013.

Milenković, M., Munćan, S \& Babić, V. (2018). Dva veka pošumljavanja Deliblatske peščare: problem šumskih požara, Šumarstvo 3-4.

JP „Zavod za urbanizam Vojvodine" (2013). Studija prostorne diferencijacije životne sredine na teritoriji APV u cilju identifikacije najugroženijih lokaliteta, Novi Sad. 
Puzović, S., Panjković, B., Tucakov, M., Stojnić, N., Sabadoš, K., Stojanović, T., ... \& Stanišić, J. (2015). Upravljanje prirodnom baštinom u Vojvodini. Novi Sad: Pokrajinski sekretarijat za urbanizam, graditeljstvo i zaštitu životne sredine i Pokrajinski zavod za zaštitu prirode.

Popović, Z., Smiljanić, M., Kostić, M., Nikić, P.\& Janković, S. (2014). Wild flora and its usage in traditional phylotherapy (Deliblato sand, Serbia, South East Europe), Indian Journal of Traditional Knowledge, vol. 13 no. 1, pp. 9-35.

Stankević, P., Pavićević, N. (1963). Deliblatski pesak: sastav - osobine - problematika. Beograd: Institut za šumarstvo i drvnu industriju SR Srbije.

Šorak, R., Rvović, I. (2016). Analiza šteta od šumskih požara u Republici Srbiji za period od 2010-2014. godine. Zbornik radova Departana za geografiju, turizam i hotelijerstvo. UDC 630*4(497.11). 